\title{
Structure and Dynamics of a Winter Colony of Bats
}

\author{
Elżbieta BAGROWSKA-URBAŃCZYK ${ }^{1}$ \& Zbigniew URBAŃCZYK ${ }^{1}$
}

\begin{abstract}
Bagrowska-Urbańczyk E. \& Urbańczyk Z., 1983: Structure and dynamics of a winter colony of bats. Acta theriol., 28, 11: 183-196 [With 2 Tables \& 4 Figs.]

Studies were made during two consecutive winter seasons, 1975-1977, of the structure and dynamics of a bat colony in the old fortifications in the Lubuskie Lake District (western Poland). Over 10,000 bats belonging to 11 species were found to hibernate. Numbers, dominance, constancy of occurrence, species diversity, capacity and density of individuals in the colony were determined. Maximum density in the population of hibernating bats was 152.6 individuals per $100 \mathrm{~m}$ of corridor. Slight differences were found in the value of the species diversity index $(\bar{H})$ between different months, and also between successive study seasons. Capacity index $(K)$ reached its maximum value at the turning point between December and January. It was found that different species appear and disappear within a given time, and that exchange of individuals takes place during hibernation. In autumn $M$. daubentoni dominated in the colony, in winter B. barbastellus, in spring $M$. myotis. There was a decrease in the numbers of bats in the colony during the course of the studies, this applying to different species to a different degree.

[Dept. of Syst. Zool., A. Mickiewicz Univ., Fredry 10, Poznań]
\end{abstract}

\section{INTRODUCTION}

The areas of western Poland are among the least investigated parts of Poland from the chripoterological aspect, since studies on bats have been carried out up to the present chiefly in southern and eastern Poland. In 1974 biology students of the Adam Mickiewicz University in Poznan undertook searches for bats in the underground corridors of the old fortifications in the Lubuskie Lake District (western Poland). Even preliminary observations showed that these underground passages are places of mass hibernation of many species of bat (Bagrowska \& Urbańczyk, 1976). Systematic studies have been carried out as from 1975 for the purpose of determining the species composition of the colony and defining its numbers, and also dominance relations, species diversity and constancy of occurrence of different species. An analysis was also made of variations in these parameters in time.

1 Present address: Osiedle Jana III Sobieskigo 26D/142, 60-683 Poznań, Poland 


\section{DESCRIPTION OF THE STUDY AREA}

The place occupied by the study colony of bats consists of the remains of fortifications in the former Międzyrzecki Fortified Region (das befestigte Gebiet Oder-Warthe-Bogen). These fortifications were constructed by the Germans during the interwar period and World War II in the Lubuskie Lake District. The most strongly fortified part runs from the village of Kęszyce to Staropole (Tarczyński, 1974) (about $8 \mathrm{~km}$ in a straight line). It includes a labyrinth of underground reinforced concrete passages at a depth of $35-50 \mathrm{~m}$ below grund level. The axis of the labyrinth is the main corridor (cross-section $3 \mathrm{~m} \times 4 \mathrm{~m}$ ) and from it side passages (about $2 \mathrm{~m} \times 2 \mathrm{~m}$ ) run in different directions. The total length of the passages is well over $30 \mathrm{~km}$. Some of them end in chambers connected by means of concrete steps with steel constructions above ground (dome). Contact with ground level is effected by means of numerous ventilation holes, small shooting openings in the steel dome and the large opening of the entry gateway

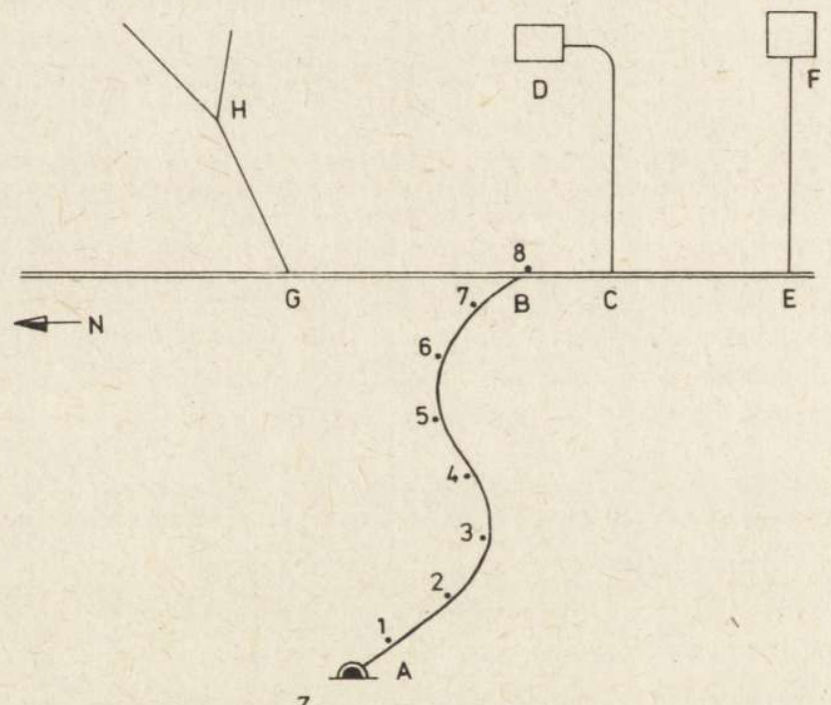

z.

Fig. 1. Plan of the part of the old underground fortifications examined in the Lubuski Lake District (diagram).

A - entry gateway to the undeground; AB - exit passage $(1500 \mathrm{~m})$; GE - part of the main passage; $\mathrm{GH}, \mathrm{CD}, \mathrm{EF}-$ side passages, $\mathrm{D}, \mathrm{F}-$ chambers, $\mathrm{Z}, 1-8-$ sites on which temperature and humidity were measured.

facing towards the west, connecting a $1500 \mathrm{~m}$ exit passage (about $3 \mathrm{~m} \times 4 \mathrm{~m}$ ) with the remainder of the labyrinth. Some parts of the passages are flooded, and in many places water drips down the walls forming varied travertine forms: stalactites, stalagmites, columns, drapery.

The studies were carried out in the part of the underground passages situated near the village of Wysoka $\left(52^{\circ} 23^{\prime} \mathrm{N}, 15^{\circ} 28^{\prime} \mathrm{E}\right.$; UTM grid square WU 30$)$ in the Gorzów voivodship, this including the exit passage $1500 \mathrm{~m}$ long, about $2 \mathrm{~km}$ of part of the main corridor and several side passages, the total length of which 
is about $3 \mathrm{~km}$. (Fig. 1). Systematic observations were made in the exit passage, while the remaining corridors were inspected sporadically.

As from 11.8.1980 these underground passages have been under protection as the "Nietoperek") Bat Nature Reserve (Urbańczyk, in press).

Temperature conditions in the part of the exit corridor examined $(0-1500 \mathrm{~m})$ vary depending on the distance from the entry gateway. In winter the temperature is lower and subject to considerable fluctuations in the parts near the cpening. Further into the interior temperature is higher and more stable (Table 1). Relative humidity in the given part was from $80-100 \%$. Distinct movement of air can be felt underground, due to the presence of ventilation openings and entries. A particularly strong draught was found in the initial part of the exit corridor (up to $500 \mathrm{~m}$ ) when western winds blew.

\section{MATERIAL AND METHODS}

The studies were made over the period of two winter seasons from September 1975 to April 1976, and from August 1976 to May 1977. Eight inspections at $4-5$ week intervals were made in both seasons, one inspection lasting $2-3$ days.

Table 1

Air temperature $\left({ }^{\circ} \mathrm{C}\right)$ on eight sites in the underground and on the exterior for the $1975 / 76$ and $1976 / 77$ seasons.

\begin{tabular}{|c|c|c|c|c|c|c|}
\hline \multirow{2}{*}{$\begin{array}{l}\text { Distance } \\
\text { from the } \\
\text { entrance } \\
\text { (m) }\end{array}$} & \multicolumn{3}{|c|}{$1975 / 76$} & \multicolumn{3}{|c|}{$1976 / 77$} \\
\hline & Min. & Max. & Mean & Min. & Max. & Mean \\
\hline Outside & -7.6 & 16.4 & 7.3 & 0.2 & 26.6 & 10.6 \\
\hline 100 & -6.0 & 8.8 & 4.3 & 0.8 & 9.3 & 5.8 \\
\hline 300 & -2.2 & 8.7 & 4.8 & 2.1 & 8.4 & 6.1 \\
\hline 500 & 0.0 & 8.3 & 5.4 & 3.3 & 7.8 & 6.2 \\
\hline 700 & 1.4 & 8.3 & 5.5 & 4.2 & 8.0 & 6.7 \\
\hline 900 & 3.2 & 8.2 & 5.9 & 4.6 & 8.0 & 6.6 \\
\hline 1100 & 5.8 & 8.4 & 6.8 & 4.8 & 8.2 & 6.8 \\
\hline 1300 & 6.3 & 8.8 & 7.2 & 5.4 & 8.4 & 7.1 \\
\hline 1500 & 7.0 & 9.4 & 8.0 & 7.1 & 9.0 & 8.3 \\
\hline
\end{tabular}

The first day of stay in the underground passage was taken as the inspection date.

All bats encountered were counted during each inspection. Whenever possible handling of the bats was limited to a minimum, i.e. when it was impossible to identify the species at a distance, or for measuring or banding. In such cases the whole operation did not last longer than 15 minutes and the bat was left in the place in which it had been found. A small number of bats of several species were released at Międzyrzecz (about $9 \mathrm{~km} \mathrm{NE}$ ) and in Poznań (about $100 \mathrm{~km} \mathrm{E}$ ). Very limited banding was carried out, and in the two seasons 625 bats of 8 species were banded.

Temperature and relative humidity were measured, the latter using an Assmann psychrometer (Table 1), during each inspection in eight places in the exit corridor. Measurements were made at a height of $1.5-2 \mathrm{~m}$. One measurement on the outside of the underground passage was made for each series of measurements. 
The following biocenotic indices were used in describing the hibernating bat coilony.

Constancy of occurrence was expressed by the eqaution:

$$
C=\left(n_{a}: N\right) 100
$$

where $n_{a}$ is the number of samples containing species $a$, while $N$ is the number of samples in the given series. One inspection was taken as one sample, and one season as one series (from autumn to the spring of the following calendar year). Dominance was expressed by the equation:

$$
D=\left(S_{a}: S\right) 100
$$

where $S_{a}$ is the sum total of individuals of species $a$, while $S$ is the number of all individuals in a multi-species colony during each inspection.

Diversity was expressed by the equation:

$$
\bar{H}=-\Sigma p_{i} \log p_{i}
$$$$
p_{i}=n_{i}: N
$$

where $n_{i}$ is the number of individuals of species $i$, while $N$ is the number of all individuals in a multi-species colony during the given inspection.

Capacity after Gaisler (1975) was expressed by the equation:

$$
K=(N: 100) \bar{H}
$$

where $N$ is abundance, and $\bar{H}$ diversity index.

\section{RESULTS}

Eleven species of bat occur in the underground passages: Myotis myotis (Borkhausen, 1797), M. bechsteini (Kuhl, 1818), M. nattereri Kuhl, 1818), M. mystacinus (Kuhl, 1819), M. brandti (Eversmann, 1845), M. dasycneme (Boie, 1825), M. daubentoni (Kuhl, 1819), Eptesicus serotinus (Schreber, 1774), Pipistrellus pipistrellus (Schreber, 1774), Plecotus auritus (Linnaeus, 1758), Barbastella barbastellus (Schreber, 1774). In view of the fact that at first no distinction was made between $M$. mystacinus and $M$. brandti, and that their differentiation on the basis of external morphological characteristics did not always give reliable results, both species were treated jointly as $M$. mystacinus. The occurrence in the passages of the two forms was confirmed by Dr. A. L. Ruprecht (pers. communication) on the basis of bone material.

M. nathalinae Tupinier, 1977 was found in the underground passages in 1980 (Bogdanowicz \& Urbańczyk, 1981; Ruprecht, 1981).

The most numerous species in the colony examined are M. myotis, $M$. daubentoni and B. barbastellus, and they also dominate there. During hibernation changes take place in the domination of different species in autumn $M$. daubentoni dominates in the colony, in winter $B$. barbastellus, in spring $M$. myotis (Fig. 2). These changes are due to the differing course taken by variation in numbers in different species.

By combining results for the two seasons it proved possible to establish the existence of regularities in the course of variations in numbers, both in the colony as a whole and among different species. The first 
bats were observed in the underground passages in August (Table 2), but the most numerous occurrence there began from September and lasted to January. In January the colony reaches maximum numbers. As from the end of January there is a drop in numbers lasting to the
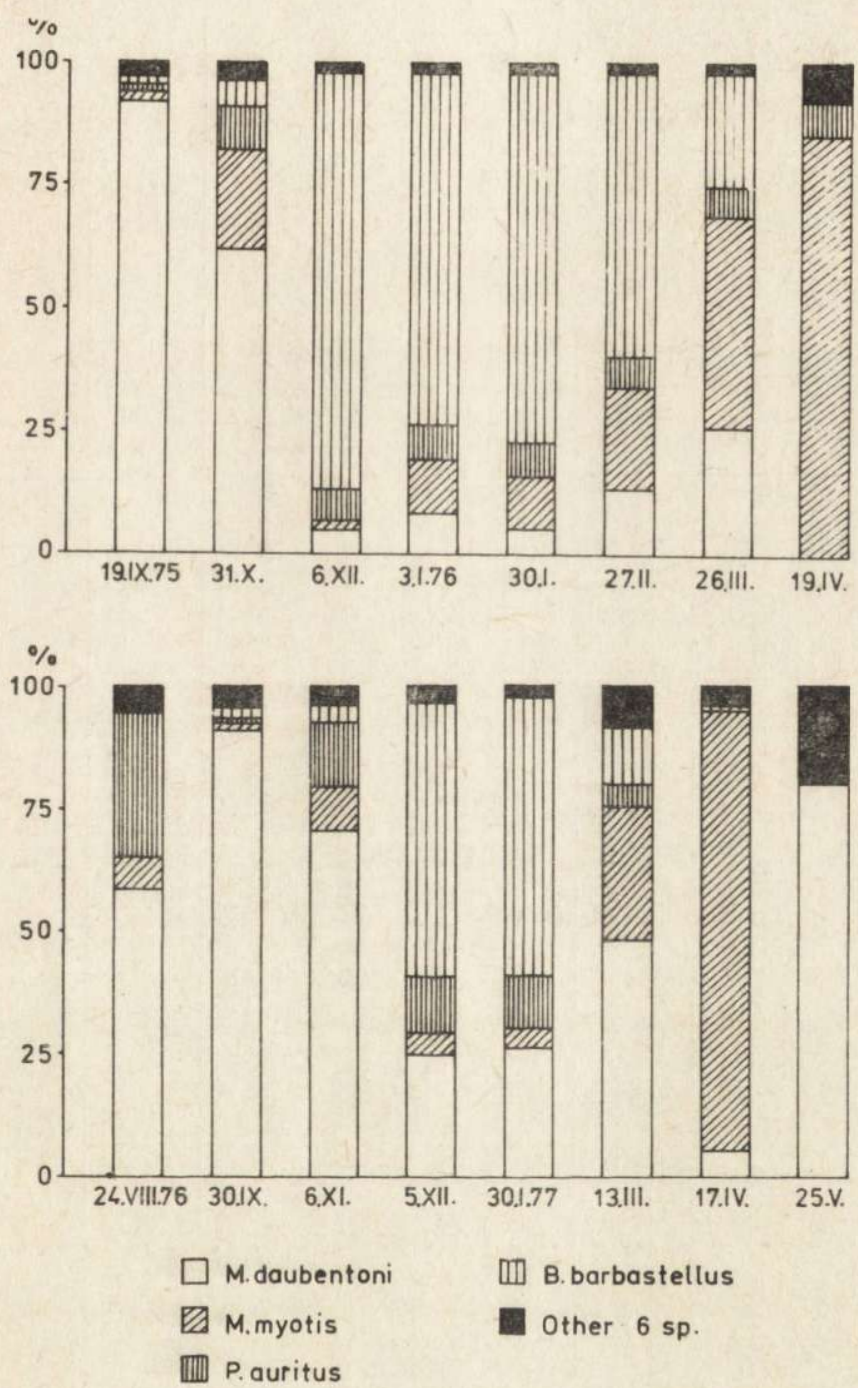

Fig. 2. Changes in domination structure of the multi-species bat colony from 1975-1977.

end of April. Single bats are still encountered in May. Different species have their own characteristic course of variations in numbers (Fig. 3).

In August and September there is an abrupt increase in the numbers of $M$. daubentoni to more than 300 individuals. This species decidedly 


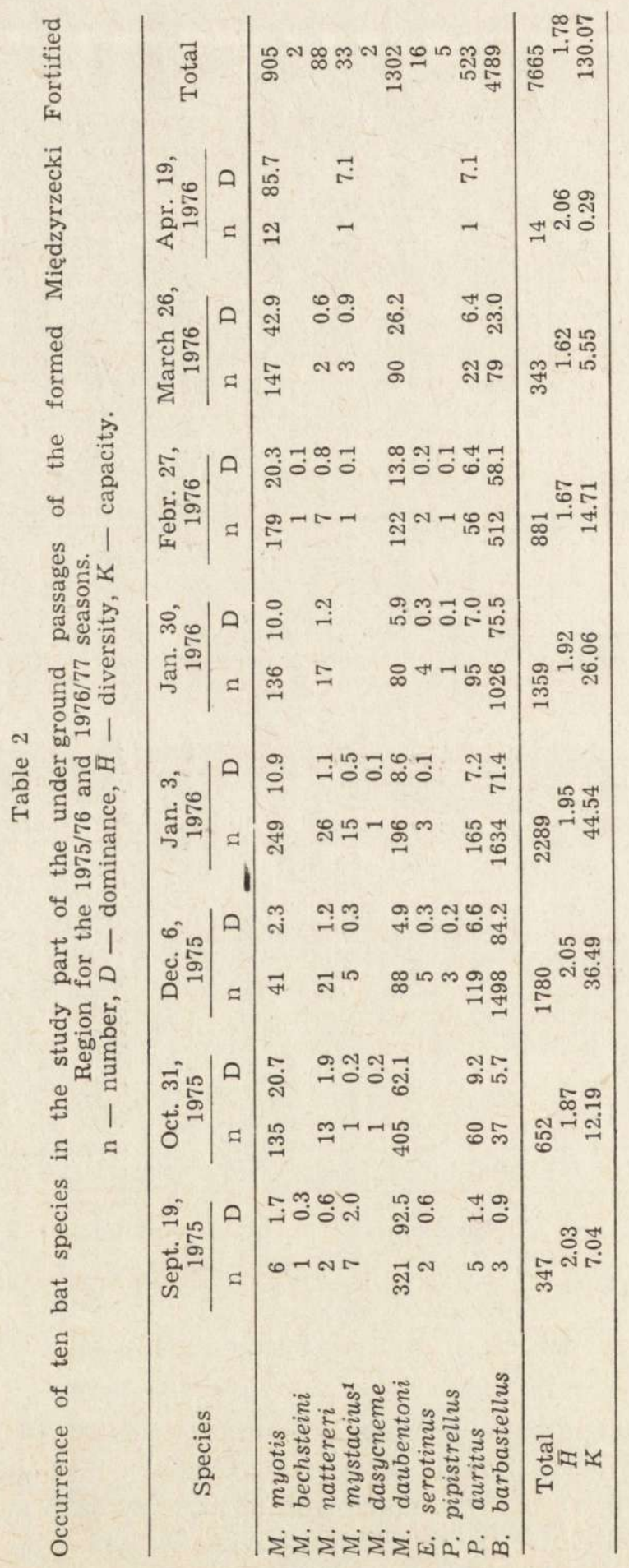




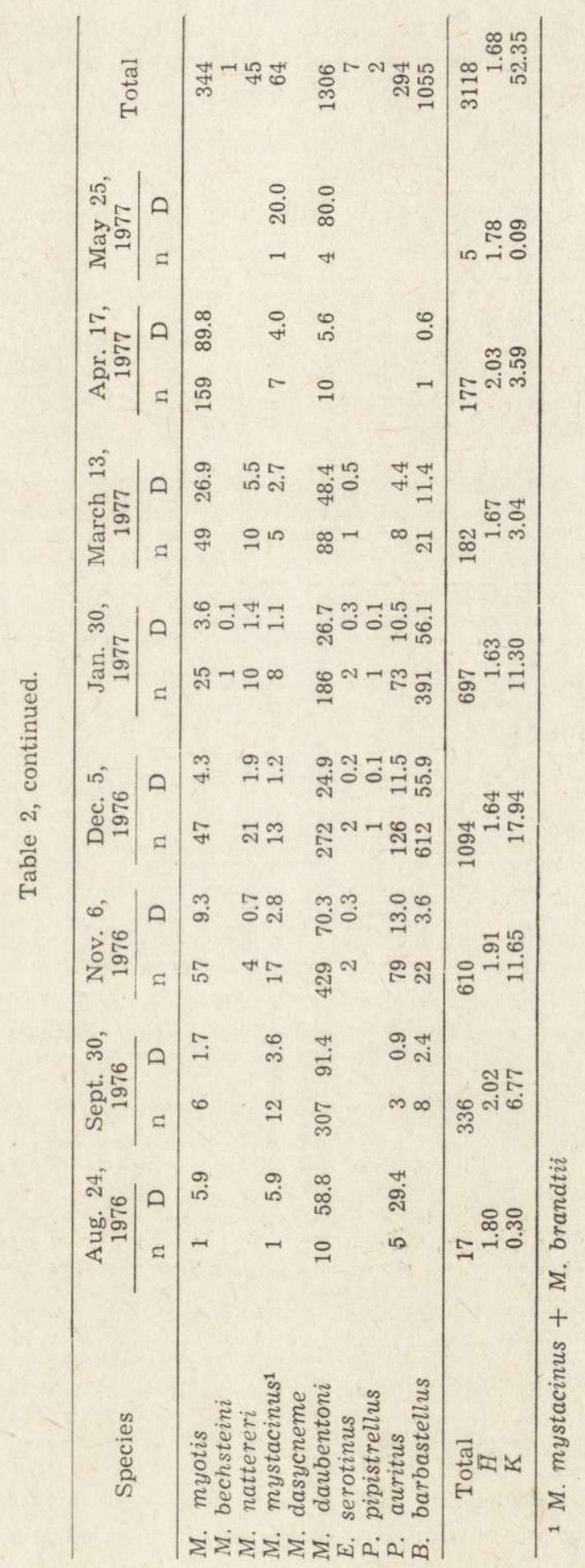


dominates during this period in the colony $\left(D=91.4 ; 92.5^{\circ} \%\right)$ (Fig. 2).

In October and November there is a further increase in numbers of different species, the numbers of $M$. myotis and $P$. auritus specially increasing, and to a lesser degree those of $M$. daubentoni and $B$. barbastellus (Table 2). The total number of bats in the part of the underground examined is more than 600 during this time. M. daubentoni

\section{M. daubentoni}
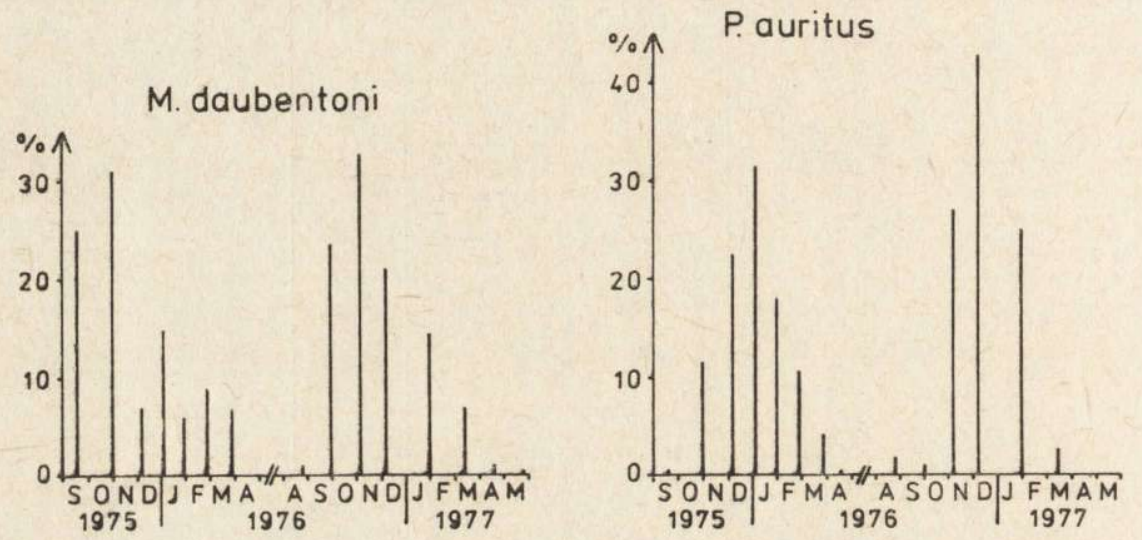

B. barbastellus
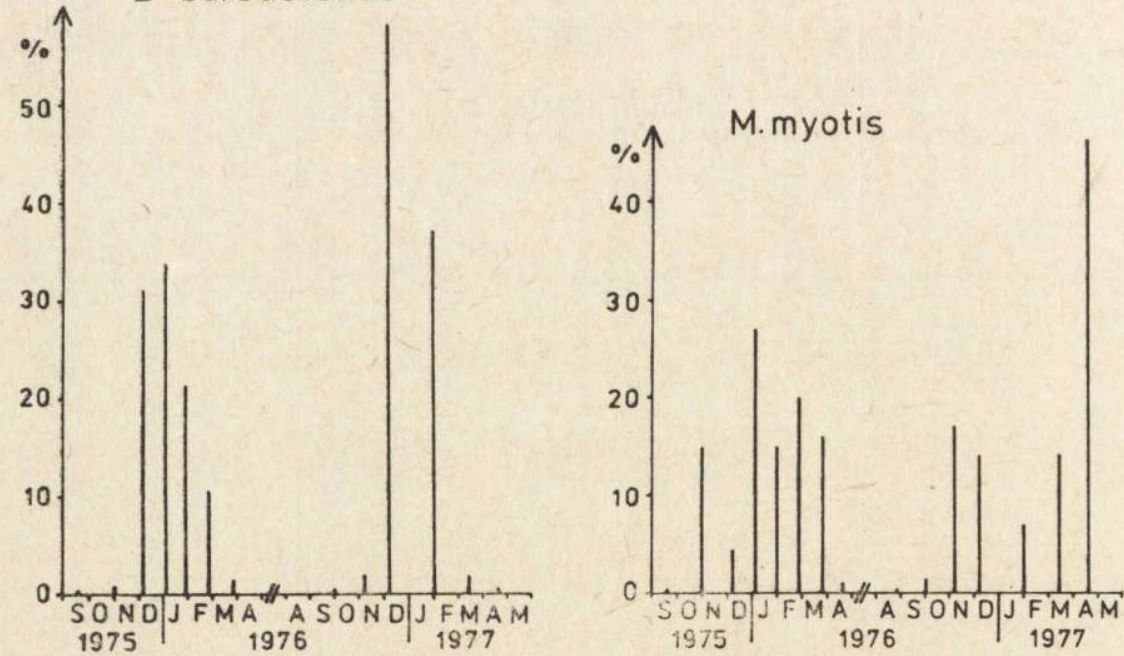

Fig. 3. Distribution of frequency of occurrence for the four most numerous species of bats in the part of the underground studied from 1975-1977.

continues to predominate among them, although there is distinct decrease in the value of its domination coefficient in comparison with the previous period ( $\mathrm{D}-61.1,70.2 \%$ ).

During the winter season (Dec., Jan., Feb.) the numbers of hibernating bats reach a maximum, the peak occurring at the end of Decem- 
ber and beginning of January (Table 2), when over 2200 individuals were found (3.1.1976). The species composition is also most diverse during these months. The percentage of different species differs completely from that observed in autumn. At approximately the turning point of November-December the numbers of $B$. barbastellus abruptly increase (Table 2, Fig. 3) so that it forms up to $75^{\circ} \%$ of the total numbers of bats during the period of its most numerous occurrence in January (Fig. 2). In February its numbers begin to decrease, but it still continues to dominate in the colony. As from December these is a decrease in the numbers of $M$. daubentoni and its domination index also decreases. The remaining species increase their numbers to approximately the beginning of January, after which there is a decrease lasting up to spring.

In March and April there is an abrupt drop in both abundance and number of species. Within three weeks (March 26-April 19, 1976) the number of bats fell from 343 (6 species) to 14 (3), M. daubentoni, B. barbastellus and $P$. auritus decreasing most rapidly. M. myotis disappears from the hibernation place more slowly, so that in April it forms more than $80 \%$ of all bats there (Table 2, Fig. 2).

Differences were found in the course taken by variations in the numbers of $M$. myotis between different seasons. During the 1975/1976 season as from September increase in numbers was found, reaching a maximum at the beginning of January. The relatively small number of individuals of M. myotis found on 6 Dec. 1975 was due to the fact that only from $0-1000 \mathrm{~m}$ of passage was inspected (this of course also applies to the remaining species). As the majority $(70-90 \%)$ of $M$. myotis hibernated during the other inspections over a length of 1000 $1500 \mathrm{~m}$, the combined number of individuals of this species in the exit passage on 6.12 .1975 may be estimated as about 200. During the season 1976/1977 the November peak in numbers was found to decrease, to be followed later by a repeat increase in March and April. An abrupt increase in the number of this species of bats found on 17.4.1977 may have been due to individuals which had hibernated further into the passages, moving towards the opening. Among the 69 individuals of M. myotis banded on 14.3 .1977 at a distance of $2500-3000 \mathrm{~m}$ from the entrance, 10 were found on 17.4.1977 in the exit passage, 9 of them at distances of $500-700 \mathrm{~m}$.

The course taken by variations in numbers in the case of $M$. daubentoni, B. barbastellus and P. auritus was almost identical in both seasons. The first of these species reached peak numbers in the underground passages in autumn (end of October/beginning of November) whereas in the case of the other two species maximum numbers were found 
during the winter months (Dec./Jan.). Among less numerous species $M$. nattereri reached peak numbers during the winter months, while differences were found in the course taken by variations in numbers in the two seasons in the case of M. mystacinus.

In both seasons greatest constancy of occurrence was characteristic of $M$. myotis, M. mystacinus, $M$. daubentoni, $P$. auritus and $B$. barbastellus (Fig. 4). The value of the constancy of occurrence coefficient (C) in different seasons was $76-100 \%$ for these species. Least constancy of occurrence was found for $M$. bechsteini (average for the two

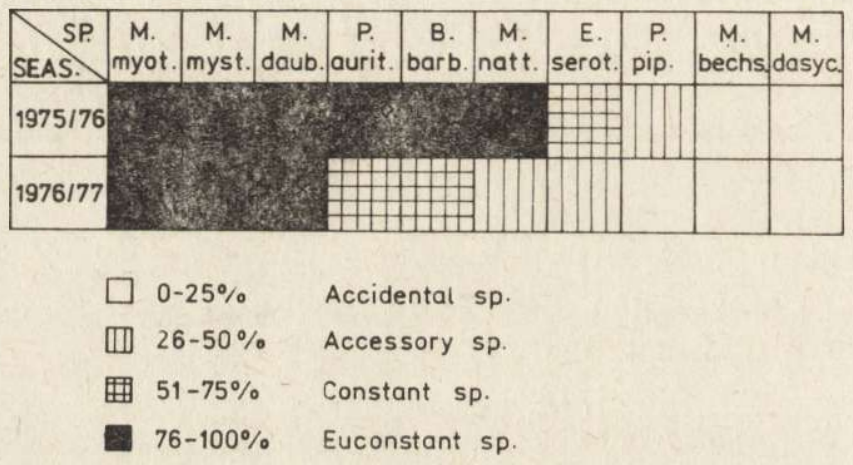

Fig. 4. Constancy of occurrence (C) for ten bat species in two seasons.

seasons $C=18.7^{0} \%$ ) and for $M$. dasycneme (average $C=12.5 \%$ ).

Table 2 gives the values for diversity index $(\bar{H})$ and capacity index $(K)$. Minimum differences only were found in the diversity index between different months, varying from 1.62 to 2.06. Differences between the two seasons were also inconsiderable. No relation was found between numbers and species diversity, which agrees with Gaisler's observations (1975). Maximum values of the capacity index were recorded in winter (Dec./Jan.). Changes in its value were correlated with respective changes in number of bats in the colony.

\section{DISCUSSION}

The results of studies so far carried out on winter colonies of bats in Europe (Bells, 1952; Strelkov, 1959; Haensel 1974; Gaisler, 1975; and many others) justify the statement that the colony we examined is one of the most interesting winter colonies of bats in Europe, on account of the unusually great numbers, for European conditions, of hibernating bats and also the variety of species there. 
Bat colonies composed of many species occur more in regions of warmer climates (Bells, 1952; Gaisler, 1966), but regardless of this it would seem that the variety of the species composition of the colony is due primarily to the diversity of the microclimatic conditions prevailing in the hibernation quarters and the abundance of places in which to shelter (crevices, niches). The number of hibernating individuals in a colony depends on the size of the hibernation quarter (Gaisler, 1975). The underground passages we inspected were very extensive, have varied climatic conditions and a very large number of shelters, providing the bats with optimum hibernating conditions. It is this which accounts for the large numbers of bats and varied species composition. It is also of significance that in western Poland there are no natural winter quarters such as are found in abundance in southern Poland. This results in all manner of artificial places of shelter, such as underground tunnels, bunkers, forts etc. being used by very great numbers of bats (unpublished data).

The relation between numbers of bats and size of hibernation quarters makes it more suitable under certain circumstances of make use of density, i.e. number of individuals $/ 100 \mathrm{~m}$ of passage than total abundance. This would for instance make it easier to compare different hibernation quarters. In chiropterological literature density of bat populations as the number of individuals/ha is usually applied to the period of summer activity (e.g. Gaisler, 1975, 1979; Zaborowski, 1976). In papers on winter colonies of bats population density in a given hibernation quarter (caves, tunnels) is rarely given. Gilson (1977) gives a density of 1.4 individual $/ 100 \mathrm{~m}$ of passage for the Zussen reserve (Belgium). In our studies the relative density of the bat population was from 0.3 (25 May, 1977) to 152.6 (3.1.1976) individuals $/ 100 \mathrm{~m}$ of passage.

As regards the species composition and proportion of different species in the underground passages we examined, the mass numbers of hibernating $B$. barbastellus and $M$. daubentoni are remarkable. Although mas hibernation of $M$. myotis is known from literature to occur (e.g. Gauckler \& Kraus, 1963; Haensel, 1974), such great numbers of hibernating bats form a unique phenomenon. The fact of the regular occurrence in winter months of $P$. pipistrellus is also interesting. This species, considered as a "tree bat" (Gaisler, 1966) is only exceptionally encountered in underground passages (Eisentraut, 1937; Haagen \& Arnold, 1955). Mass hibernation of this species in caves has been however found in Roumania, where abount 100,000 individuals hibernate every year in the Sure-Mare cave (Dumitrescu \& Orghidan, 1963). The fact of the regular hibernation of $M$. bechsteini, one of the rarest European species of bat, is also remarkable. 
When analyzing the data contained in table 2 it must be concluded that there was a drop in the numbers of the colony during the studies. When analogical periods for the two seasons are compared, however, (30.1.1976 and 30.1.1977) differences are found in the course taken by variations in number of different species. In the case of $B$. barbastellus, M. myotis, $P$. auritus and M. natterari, a drop in number is observed, whereas numbers of $M$. daubentoni and $M$. mystacinus increased considerably. One of the reasons for the smaller numbers in the colony during the second season might have been the milder winter of 1976/77 (Table 1), which might in particular account for the less numerous occurrence of B. barbastellus (Krzanowski, 1959; Rybár, 1975). The actual studies, which disturbed the bats, may also have contributed to the decrease in their numbers. The negative effect of the anthropogenic factor (including scientific studies, combined with mass banding) on the bat population has frequently been found (Sluiter \& Heerdt, 1957; Stebbings, 1966; Rybáŕ, 1973). In our studies inspections were made eight times during the season and, as Gaisler states (1975), a decrease in the number of bats may take place when inspections are made more often than once a year. It would, however, appear that the method we adopted, limiting disturbance of the bats to a minimum, could not have had a decisive effect on the decrease in the numbers of the colony. It is certain that tourist visits played a more important part in this cave. Instances of vandalism were frequently observed: destruction of the formations caused by dripping, lighting bonfires, disturbance or even killing of hibernating bats. It is, however, difficult to find an explanation for the increase in numbers of $M$. daubentoni and $M$. mystacinus. It must be observed here that in hibernating quarters in both Belgium (Gilson, 1974; Fairon, 1981) and Holland (Daan, 1980) increase in the numbers of $M$. daubentoni and $M$. mystacinus have been observed of recent years, with a simultaneous distinct drop in the numbers of other species. According to Gaisler (1975) variations in the numbers of different species of bats are negatively correlated with the degree of their return rate. The numbers of species with a lower degree of "fidelity" to winter hibernating quarters (M. mystacinus, M. nattereri, $M$. daubentoni, $P$. auritus) increased during his studies, while number of species with a higher degree of "fidelity" (M. myotis, B. barbastellus) decreased.

Our studies showed that the phenomenon of hibernation by bats is dynamic in character. During the hibernation season there is an exchange of individuals, different species appear and disappear at a given period (cf. also Verschuren, 1949; Bells, 1952; De Wilde \& van Nieuwenhoven, 1954; Krzanowski, 1959). Among hibernating species of 
bats a large number are known to wake frequently and move to a new place (cf. Davis, 1970).

Acknowledgements: We wish to thank Professor W. Skuratowicz for his help and supervision during the course of our studies, Dr. A. L. Ruprecht for his assistance and valued comments and Professor $Z$. Pucek for his constructive criticism of the first version of the present paper and all the goodwill he showed us.

\section{REFERENCES}

1. Bagrowska E. \& Urbańczyk Z., 1976: Stanowisko nietoperza Myotis bechsteini (Kuhl) na Pojezierzu Lubuskim. Przegl. zool., 20: 367-369.

2. Bells L., 1952: Fifteen years of bat banding in the Netherlands. Publ. natuurh Genoot. Limburg, 5: 1-99.

3. Bogdanowicz W. \& Urbańczyk Z., 1981: A record of Myotis nathalinae Tupinier, 1977 from Poland. Acta theriol., 26: 427.

4. Daan S., 1980: Long term changes in bat populations in the Netherlands: a summary. Lutra, 22: 95-118.

5. Davis W., 1970: Hibernation: ecology and physiological ecology. [In: "Biology of Bats". Ed. Wimsatt W.]. Academic Press: 265-300. New York.

6. Dumitrescu M. \& Orghidan T., 1963: Contribution à la connaissance de la biologie de Pipistrellus pipistrellus Schreber. Annls Spéléol., 18: 511-517.

7. Eisentraut M., 1937: Die deutschen Fledermäuse. Eine biologische Studie. Paul Schöps: 1-184. Leipzig.

8. Fairon J., 1981: Protection des Chiroptères en Belgique. Myotis, 18-19: 23-26.

9. Gaisler J., 1966: A tentative ecological classification of colonies of the European bats. Lynx, 6: 35-39.

10. Gaisler J., 1975: A quatitative study of some populations of bats in Czechoslovakia (Mammalia: Chiroptera). Acta Sci. Nat. Brno, 9: 1-44.

11. Gaisler J., 1979: Results of bat census in a town (Mammalia: Chiroptera). Věst. čsl. zool. Spol., 43: 7-21.

12. Gauckler A. \& Kraus M., 1963: Uber ein Massenquartier wintersehlafender Mausohren (Myotis myotis) einer Höhle der Frankenalb. Bonn. zool. Beitr. 14: $187-205$.

13. Gilson R., 1974: Quelques aspects de l'écologie des Cheiroptères de Belgique et causes principales de leur déclin. Bull. Rés. nat. orn. Belg., 21: 17-21.

14. Gilson R., 1977: Trois années d’observations dans la réserve souterraine de Zussen. Bull. Rés. nat. orn. Belg., 25: 49-53.

15. Haagen G. \& Arnold J ,,1955: Zur Uberwinterung von Pipistrellus pipistrellus (Schreber, 1774). Säugetierkdl. Mitt., 3: 122.

16. Haensel J., 1974: Uber die Beziehungen zwischen verschiedenen Quartiertypen des Mausohrs, Myotis myotis (Borkhausen, 1797) in den brandenburgischen Bezirken der DDR. Milu, 3: 542-603.

17. Krzanowski A., 1959: Some major aspects of population turnover in wintering bats in the cave at Puławy (Poland). Acta theriol., 3: 27-42.

18. Ruprecht A. L., 1981: Variability of Daubenton's bat and distribution of the nathalinae morphotype in Poland. Acta theriol., 26: 349-357. 
19. Rybář P., 1973: Remarks on banding and protection of bats. Period. biol., 75: $177-179$.

20. Rybáŕ P., 1975: Hibernation of the barbastelle, Barbastella barbastellus (Schreber, 1774) in a man-made hibernation quarter. Zool. Listy, 24: 113-124.

21. Sluiter J. \& Heerdt van P., 1957: Distribution and decline of bat populations in S. Limburg from 1942 till 1957. Nat. Maandb., 46: 134-143.

22. Stebbings R., 1966: Bats under stress. Stud. Speleol., 1: 168-173.

23. Strelkov P., 1959: Materjaly po zimovkom letučich myšej v evropejskoj časti SSSR. Trudy zool. Inst., Leningr., 25: 255-303.

24. Tarczyński M., 1974: Międzyrzecka „linia Maginota”. Mówią Wieki, 8: 30-35.

25. Urbańczyk Z., in press: „Nietoperek” - das erste Reservat von Fledermausen in Polen. Waldhygiene.

26. Verschuren J., 1949: L'activité et les deplacements hivernaux des Cheiroptères en Belgique. Bull. Mus. r. Hist. nat. Belg., 25: 1-27.

27. Wilde de J. \& Nieuwenhoven van P., 1954: Waarnemingen betreffende de winterslaap van vleermuizen. Publ. natuurh. Genoot. Limburg, 7: 51-83.

28. Zaborowski S., 1976: Badania nad nietoperzami $z$ punktu widzenia ich pozycji w ogniskowo-kompleksowej metodzie ochrony lasu. Pr. Inst. badaw. Leśn., 493: $137-145$.

Accepted, February 25, 1983.

Elżbieta BAGROWSKA-URBAÑCZYK i Zbigniew URBAŃCZYK

\section{STRUKTURA I DYNAMIKA ZIMOWEJ KOLONII NIETOPERZY}

\section{Streszczenie}

W dwu kolejnych sezonach zimowych 1975-1977 badano strukturę i dynamikę kolonii nietoperzy $w$ podziemnych tunelach starych fortyfikacji na Pojezierzu Lubuskim. Podczas 16 kontroli stwierdzono zimowanie wielu tysięcy nietoperzy 11 gatunków (Tabela 2). Zagęszczenie populacji zimujących nietoperzy wynosiło od 0,3 (25.V.1977) do 152,6 (3.I.1976) osobników/100 m korytarza.

Dużą liczebność i bogaty skład gatunkowy autorzy tłumaczą rozległością podziemi, różnorodnością warunków mikroklimatycznych dużą ilością schronień (szczelin, nisz) oraz brakiem naturalnych kryjówek zimowych w tej części Polski. Sen zimowy nietoperzy ma charakter dynamiczny, poszczególne gatunki pojawiają się : ubywają o określonej porze (Tabela 2, Rys. 3), w ciągu sezonu następuje też wymiana osobników. Jesienią dominuje w koloni $M$. daubentoni, zimą $B$. barbastellus, wiosną M. myotis (Rys. 2). Analiza wskaźników różnorodności gatunkowej $(\bar{H})$ wykazała minimalne różnice między poszczególnymi miesiącami jak i między badanymi sezonami. Nie stwierdzono zależności między liczebnością nietoperzy a różnorodnością składu gatunkowego. Wskaźnik pojemności $(K)$ maksymalną wartość osiągał w grudniu-styczniu (Tabela 2). Obserwowano spadek liczebności kolonii w trakcie badań, przy czym w różnym stopniu dotyczył on poszczególnych gatunków (Tabela 2). 